ارزيابى مدل استنباط خاى (SIE) در نقشهبردارى خاك با تأكيد بر استفاده از دانش كارشناس

$$
\text { و منطق فازى (شهرستان جلفا -كلفرج) }
$$

جكيده

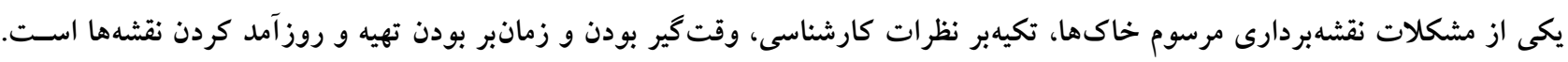

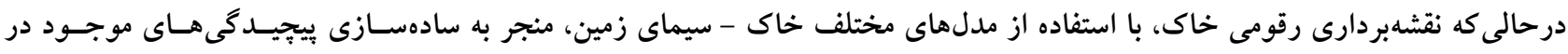

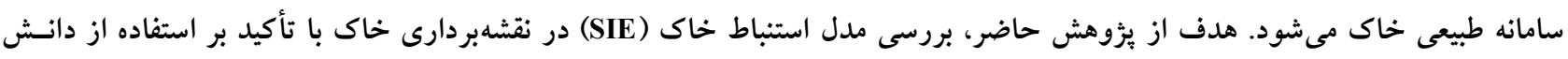

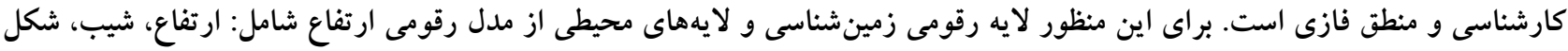

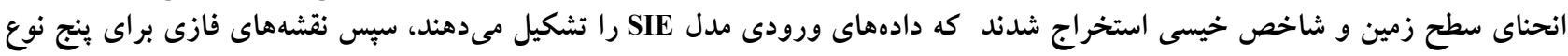

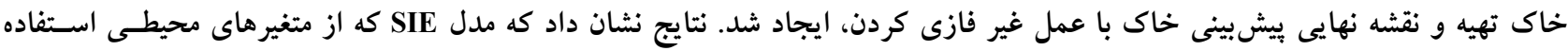

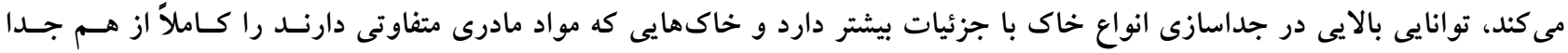

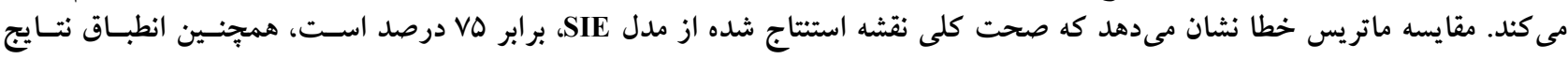

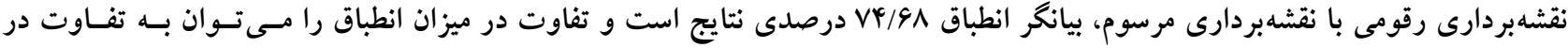
ماهيت دو روش مرتبط دانست.

وازههاى كليدى: نقشهبردارى رقومى خاك، مدل رقومى ارتفاع، منطق فازى، مدل SIE 
خاى - سيماى سرزمين، بيـانكر شـكل سـادهشـدهاى از روابـط

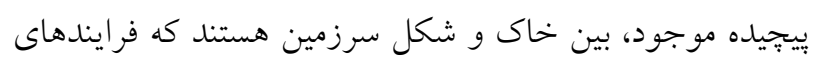

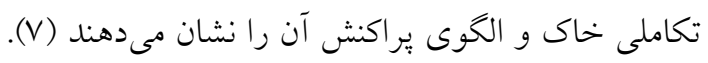

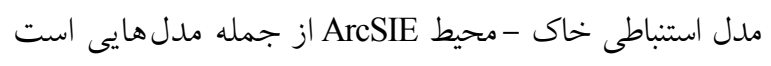

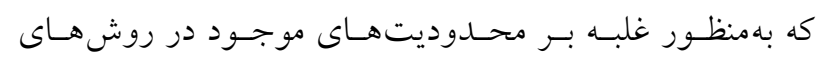

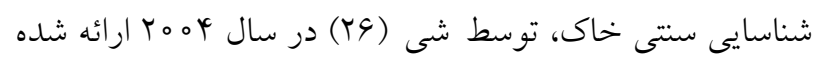
است. در اين مدل، نقشه خاك بر پايه مدل خاك محسيط ايجـاد مىشود، بدين معنا كه خاك تابعى از عوامل محيطى است. $\mathrm{S}=f(\mathrm{E})$

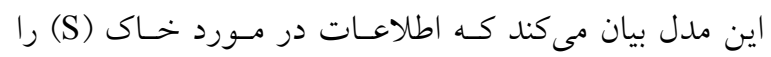

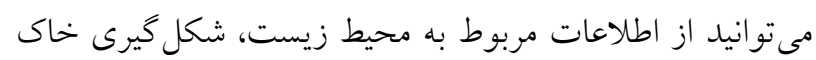

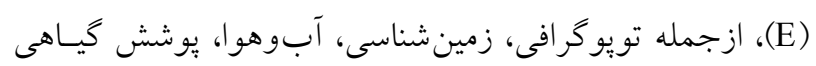

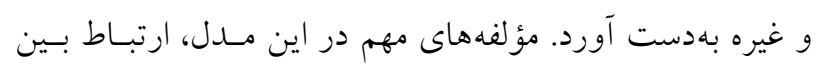

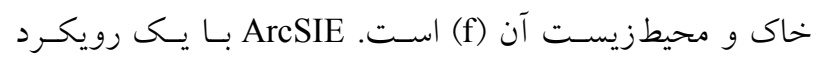

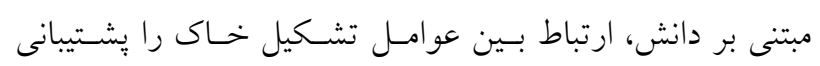

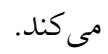

ArcSIE با دو نوع دانش كار مى كند: يكى استدلال قاعدههـا

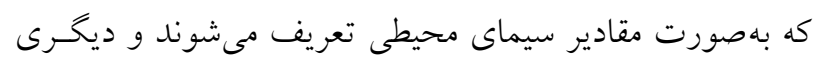

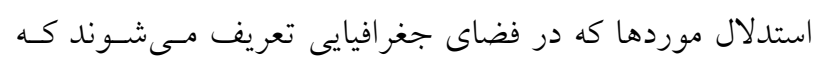

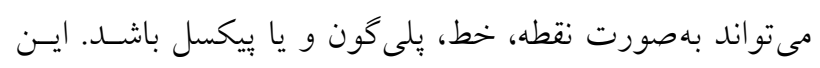

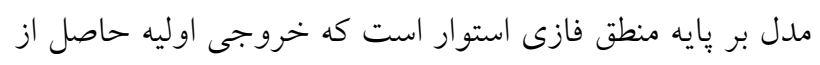

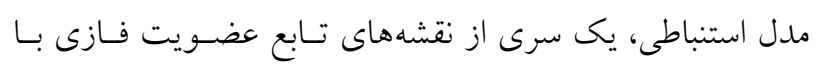

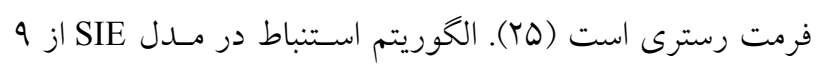
تابع P، E و T تشكيل شده و به شكل شكل زير است:

$\mathrm{S}_{\mathrm{ij}, \mathrm{k}}=\mathrm{T}_{\mathrm{k}}\left\{\mathrm{P}_{\mathrm{c}}\left[\mathrm{E}_{\mathrm{c}, \mathrm{a}}\left(\mathrm{Z}_{\mathrm{ij}, \mathrm{a}}, \mathrm{Z}_{\mathrm{c}, \mathrm{a}}\right)\right\}\right.$

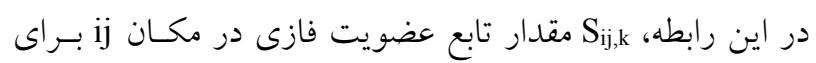

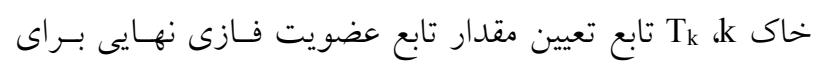

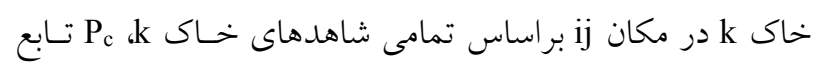

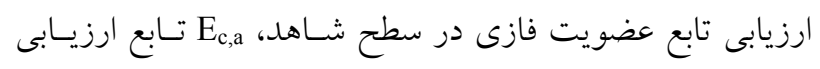

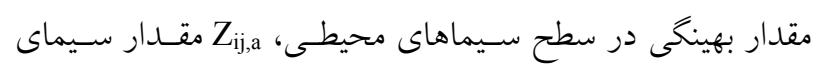

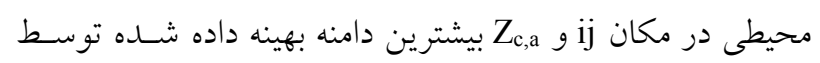

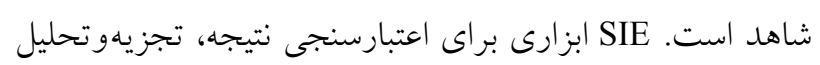

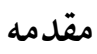

روشهاى معمول بررسى خاكها از نظر زمان و هزينه مورد نياز

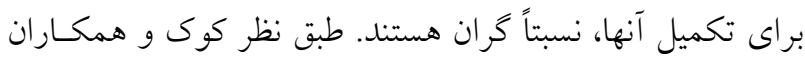

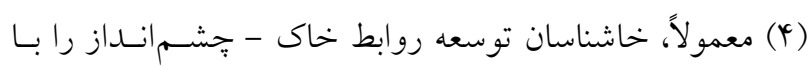

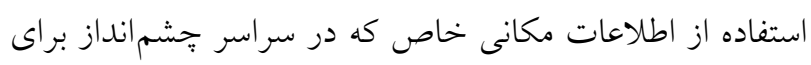

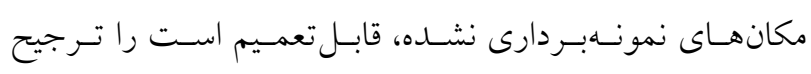

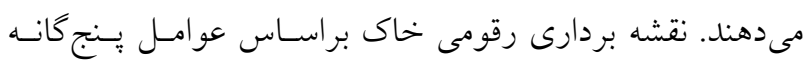
تشكيل خاى و اطلاعات منتج شده از متغيرهـاى كمكى خـى خـاى بردي

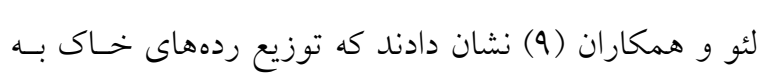

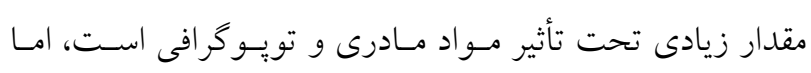

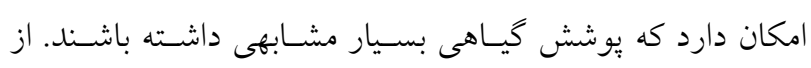

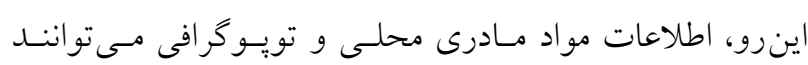

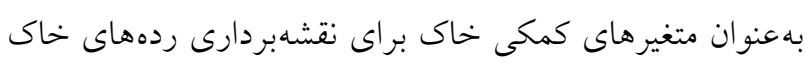

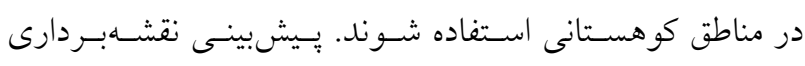

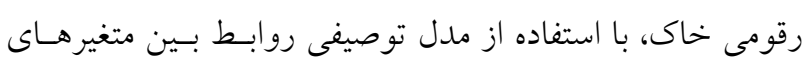
كمكى خاك و خاى اجرا مىشود (10).

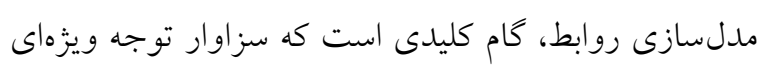

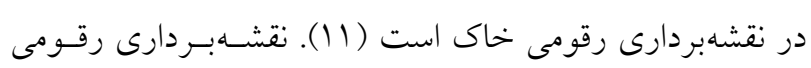

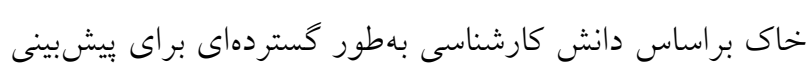

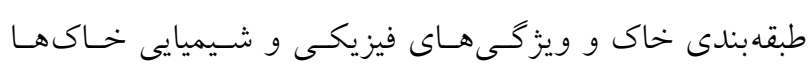

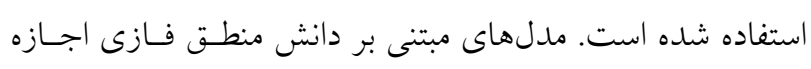

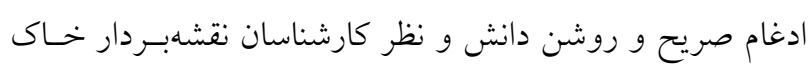
آشنا به منطقه را مىدهد (IV) شناسايى رقومى خاكها بهعنوان ابزارى براى ايجاد اطلاعـات رهات

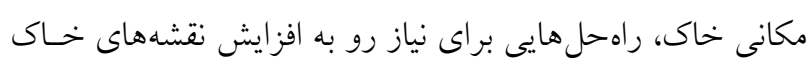

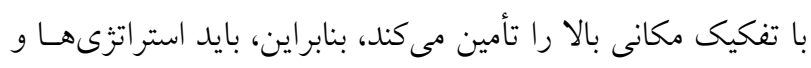

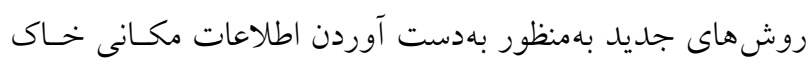
با تفكيك مكانى بالا توسعه يابد (19 و ع (Y).

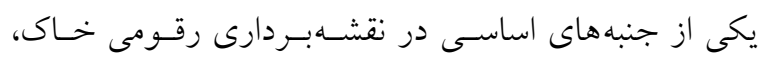

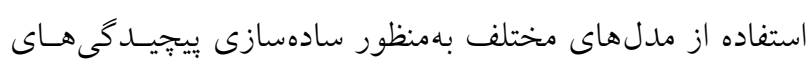

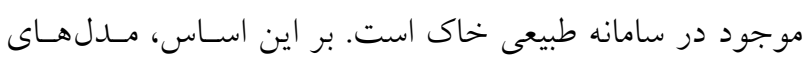


منطقه كلفرج شهرستان جلفا استان آذربايجان شرقى است.

مو اد و روش ها معرفى منطقه مطالعاتى

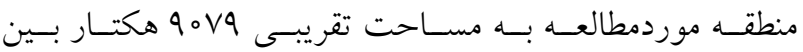

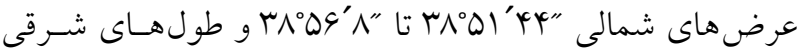

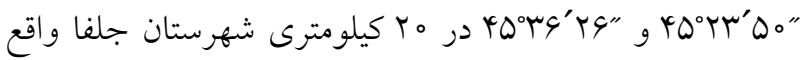

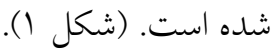
برمبنـاى دادههــاى هواشناسـى (1)، رزيــمهـاى رطـوبتى و حرارتى خاى منطقه مطالعاتى، زريكى و مزيك هسـتند. سـيماى سرزمين در اين منطقه، شامل تيبٍ اراضى كوهها و آبرفـتهـاى بادبزنى شكل سنگريز مدار است.

نمونهبردارى خاك و مطالعات آزمايشخاهى اطلاعـات خـاك جمـع آورى شــده از منطقـهـ مطالعـاتى، شـامل اطلاعات حاصل از تشـريح، نمونسهـــردارى و نتـايج فيزيكسى و شيميايى VV خاكرخ در منطقه كلفرج (شكل r) هستند. تمامى خاكرخ هاى حفرشده، براسـاس راهنمـاى تشـريح و نمونهبـردارى خـاكهـا در صـحرا (Y M و (Y) تشـريح شـدند و مطابق با كليد ردهبندى آمريكايى خاك (YN) طبقهبندى شــند و درنهايت، از تمامى افقهاى زنتيكى آنهـا نمونسهـــــدارى انجـام كُفت. سيس، آزمايش هاى فيزيكى و شيميايى مورد نياز شـامل درصـــ ذرات درشـت، واكــش خــاك، خـل اشـباع، هــــايت الكتريكى عصاره اشباع، بافـت خــاك و اجـزاى آن، ميـزان كـل

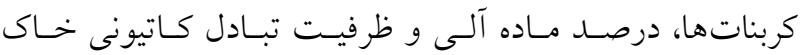
براساس روشهاى استاندارد روى نمونهها انجام گرفت (Yo) و

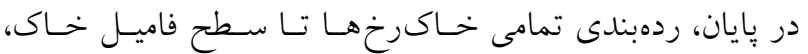
براساس نتايج آزمايشخاهى و مطابق با كليد ردهبندى آمريكـايى خاى (YN)، نهايى شد.

\section{تهيه دادهاى رقومى و يردازش آنها}

بهمنظور ايجاد لايههاى رقومى ورودى مدل، لايه رسـترى مــل
زمين، قبل و بعد از بردازش دادههاى رسترى براى تبديل فرمت

اطلاعات فراهم مى كند (TO).

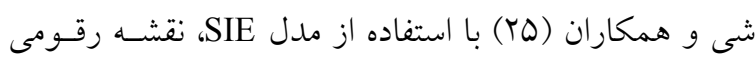

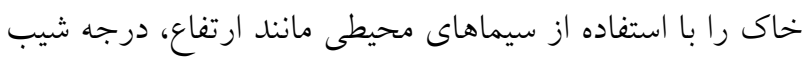

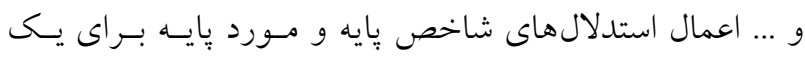

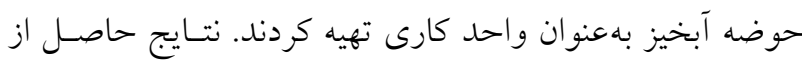
مقايسه نقشه توليدى مدل SIE و نقشه سنتى، بيـانكر كيفيـت و و دقت قابل قبول نقشه رقومى توليد شده توسط مدل بود.

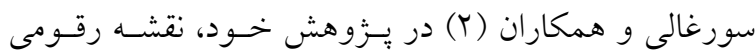

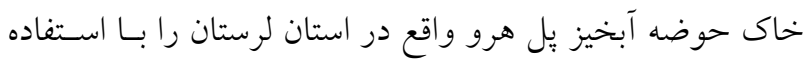
از مــدل اسـتنباط خــاك SIE، در محـيط ســامانه اطلاعــات جغر افيايى، توليد كردند، همجنين بهمنظـور اعتبارسـنى نقشـه رقومى خاك توليدى، نقشه خاك منطقه به روش سـنتى تهيـه و ماتريس خطاى حاصل از مقايسه دو نقشه را محاسـبه كردنـد و

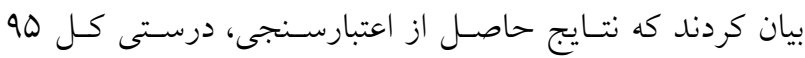

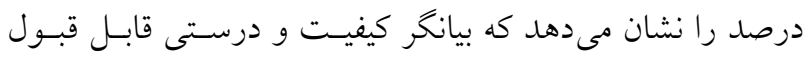
نقشه رقومى خاك توليدشده توسط مدل استباط خاك است. اسميت و همكاران (YV) نيز با استفاده از مدل SIE، اقدام به تهيه نقشه رقومى خاك منطقهاى در جنوب بريتيش كلمبيا كانادا

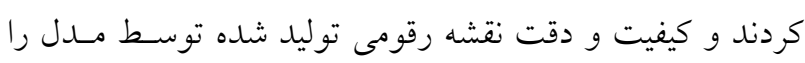

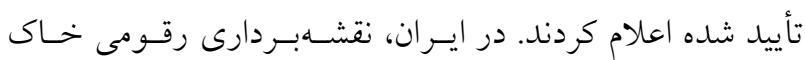

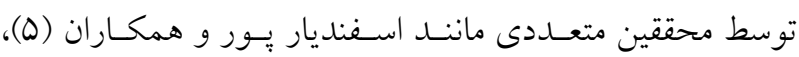

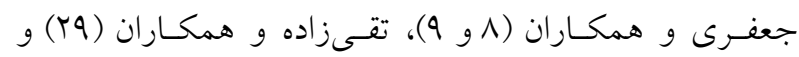

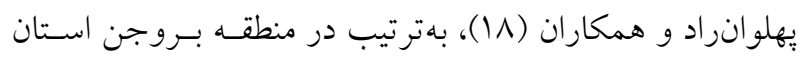

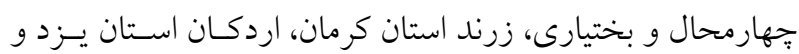

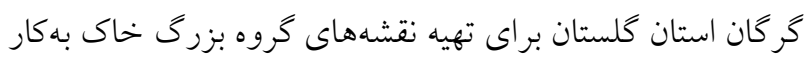

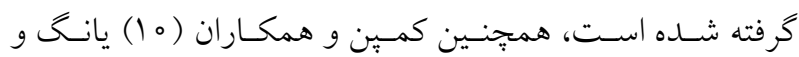

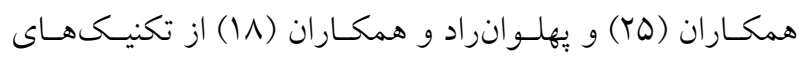

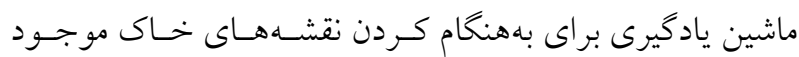

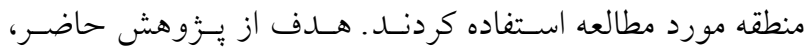
نقشهبردارى خاك بهوسيله دانش كارشناسان و منطق فـازى بـا

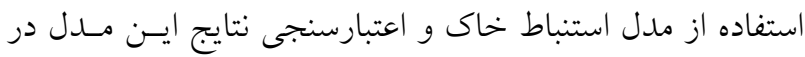




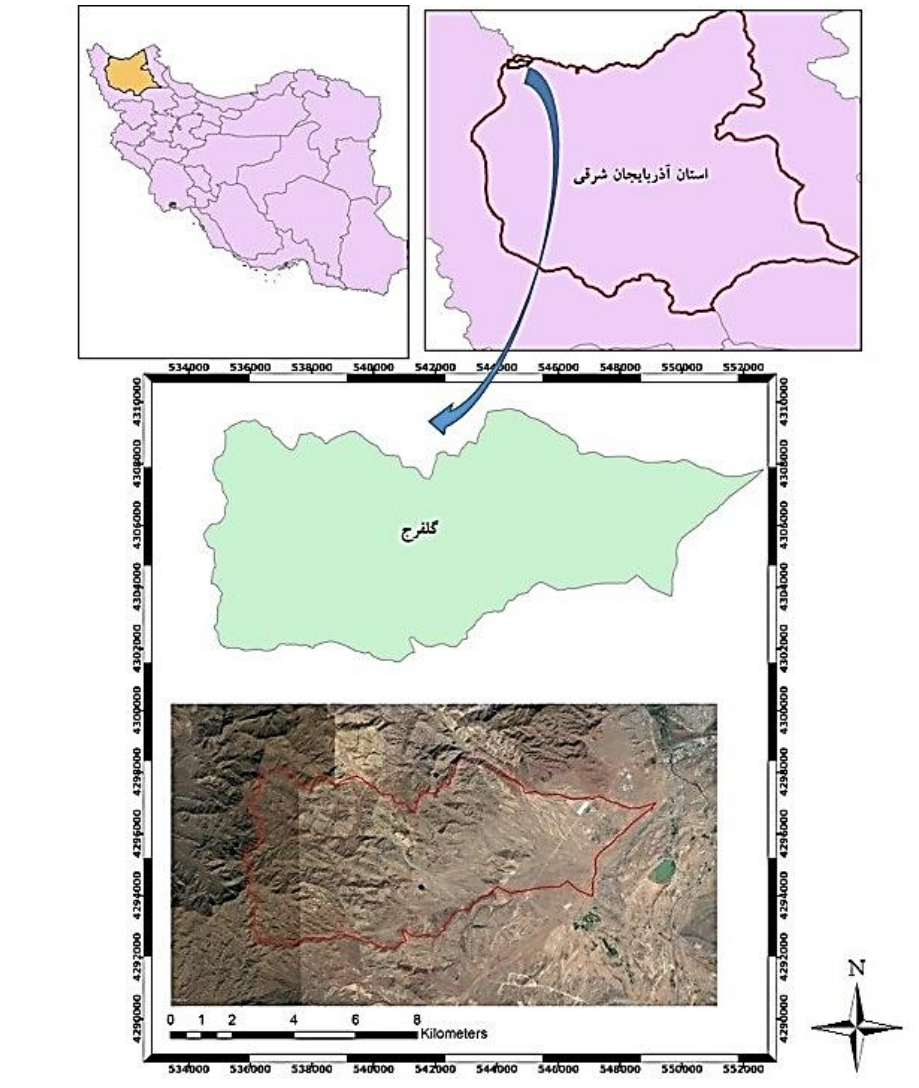

شكل ا. موقعيت منطقه مورد مطالعه در شهرستان جلفا، استان آذربايجان شرقى

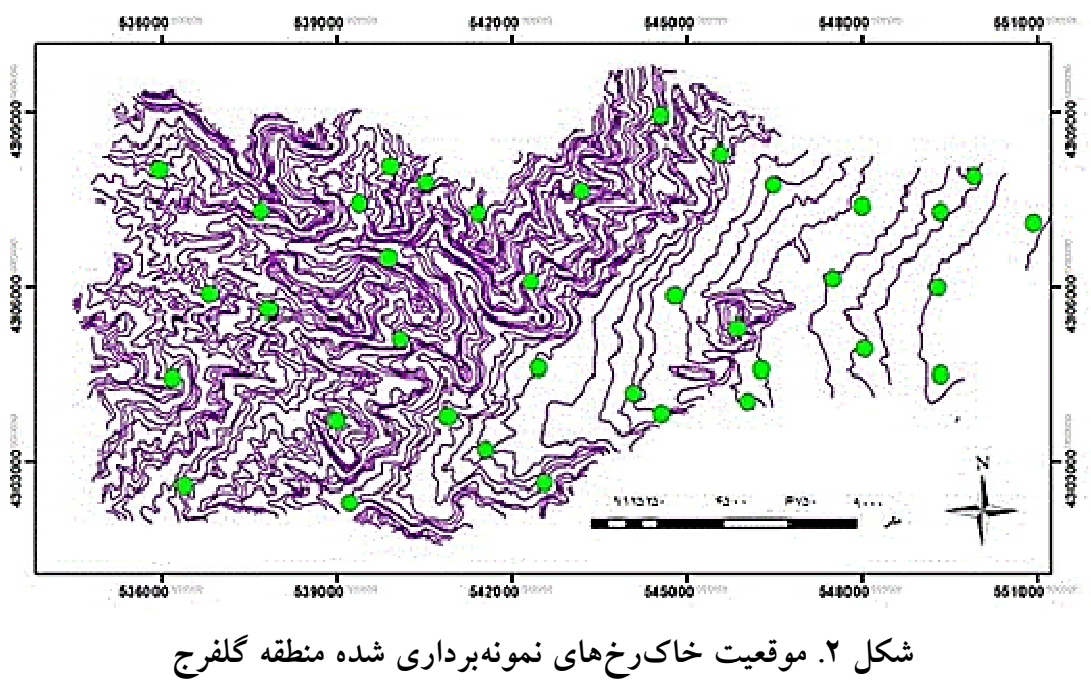

سـازمان زمسينشناسـى كثـور، در محسيط سـامانه اطلاعـات

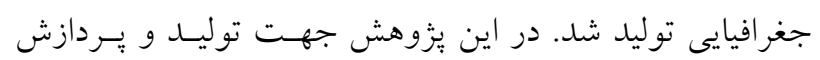

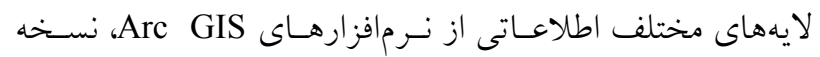

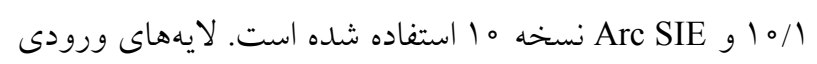

رقومى ارتفـاع (DEM) زمسين مرجـع توليــ شــده از دادهــاى

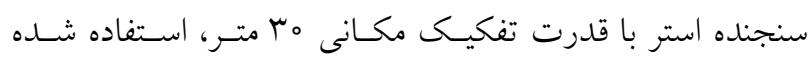

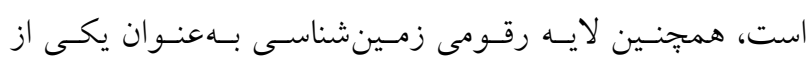

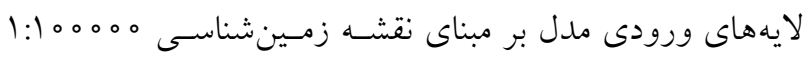



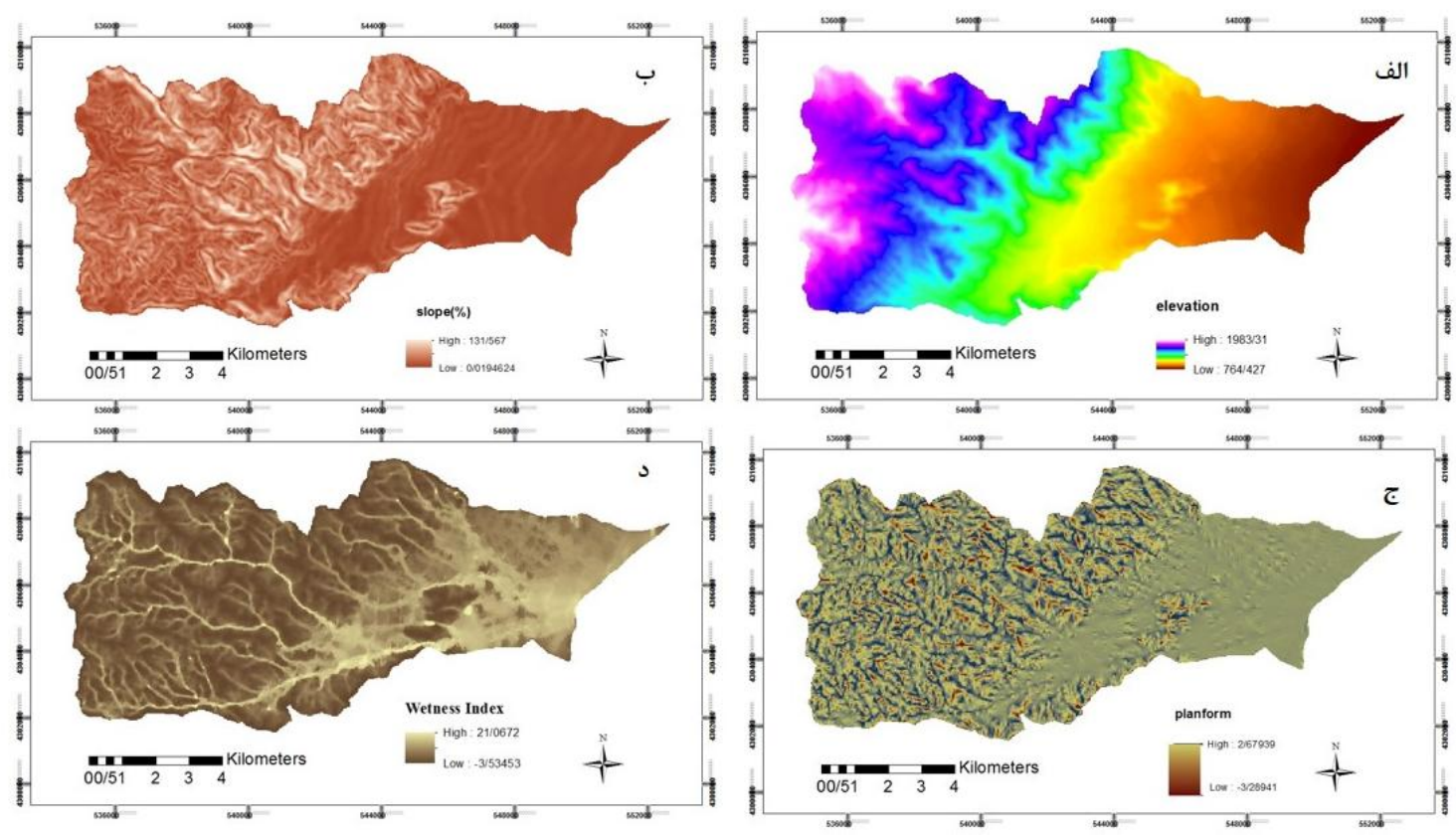

شكل r. الف) نقشه ارتفاع، ب) درجه شيب برحسب درصد، ج) شكل انحناى سطح زمين و د) شاخص خيسى منتج شده از مدل رقومى ارتفاع منطقه مورد مطالعه توسط مدل SIE

مىشود كه در مقايسه با الخوريتم تك مسير شاخص خيسى كـه نشان دهنده جريان در بالاترين جهت است، نتايج بهتـرى ارائـه مى كند. قوانين نهايى در جدول ( (1)ششان داده شده است، شـكل (Y) نمونهاى از رابط استنتاج را نشان مى دهد كـه نشـان دهنـــه تابع عضويت است. تابع عضويت فاكتور محسـود كنـــه ArcSIE بـا اسـتفاده از متغيرهاى كمكى زيستمحيطى و متغيرهاى شـكل زمسين بـراى يى بــردن بـه نـوع خـاك اسـت. تـابع فـاكتور محسدود كنــده، بيكربندى زيستمحيطى در يك محل خاص را براى سرىهـاى خاى باهم مقايسه مسىكنـــ و حسـاقل مقــار بهينخـى در ميـان متغيرهاى كمكى بارزش بهينه كلى را بــراى آن مكـان انتخــاب مى كند. مدل ArcSIE براى ينج تيٍ خاك، يك تـابع عضسويت فازى شبكهاى (رسترى) براى هر كدام از انواع خاى ارائه مى كند. هر بيكسل از اين توابع عضويت فازى، عددى بين صفر تاصد را به خود اختصاص مىدهد. نقشههاى تابع عضويت فـازى ايجـاد شده غير فازى مى شوند. در طى فرايند غير فازى كردن، خاى با

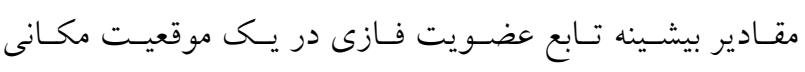

مدل SIE، لايه رقومى زمينشناسى و لايههاى محيطى منتج شده

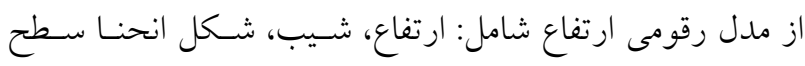
زمين و شاخص خيسى هستند (شكل س). از ويزگى هاى زمين توليد شده (شـيب و شـاخص خيسىى) بهوسيله SIE، استفاده شد. بهمنظـور توليــ لايـهـهـاى عـوارض سطحى (مانند لايه درجـهـ شـيب و شـكل انحنـا سـطح) انـدازه همسايخى هب متر و بهمنظور محاسبه از الكوريتم ايوانز - يانح

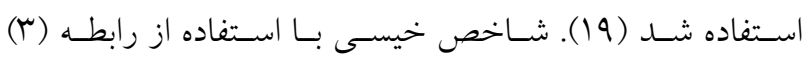
محاسبه شد:

WI = ln (درجه شيب/جريان تجمعى) در اين رابطه، WI شـاخص خيسى اسـت كـه از بـا در دسـت داشتن جريان تجمعى و درجه شيب محاسبه مسىشـود. در ايسن مطالعه با استفاده از DEM ورودى اصلاح شده، الخـوريتم جنــ

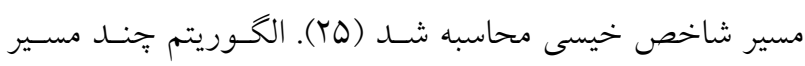

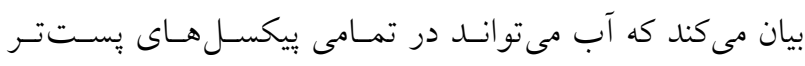
مجاورش جريان يابد و توزيع مقدار آب بيكسل هـاى يسـت بـــــ توسط درجه شيب بين آن بيكسلهـا و بيكسـل مركـزى تعيسين 
جدول ا. قوانين براى خاكهاى نوع يك تا ينج

\begin{tabular}{|c|c|c|c|c|c|c|}
\hline \multicolumn{2}{|c|}{ تابع P } & \multicolumn{2}{|c|}{ شكل منحنى } & \multicolumn{2}{|c|}{ عضويت كامل } & \multirow{2}{*}{ 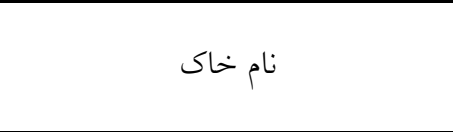 } \\
\hline 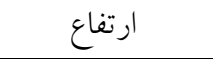 & 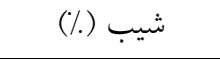 & 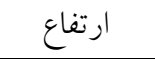 & 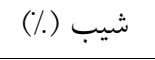 & ارتفاع (m) - (m) & 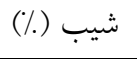 & \\
\hline Limiting Factor & Limiting Factor & Bell-shape & Bell-shape & IVoo & rQ & خاى نوع يك (Lithic Xerorthents) \\
\hline Limiting Factor & Limiting Factor & Bell-shape & S-shape & 1994 & ro & خاك نوع دو (Lithic Haploxerepts) \\
\hline Limiting Factor & Limiting Factor & Bell-shape & S-shape & $|r| \Lambda$ & ro & خاك نوع سه (Calcic Haploxerepts) \\
\hline Limiting Factor & Limiting Factor & Bell-shape & Z-shape & $90 / / r$ & $\wedge$ & خاى نوع جهار (Typic Calcixerepts) \\
\hline Limiting Factor & Limiting Factor & Bell-shape & Z-shape & $9 \circ \wedge / 9$ & Q & خاك نوع ينج (Typic Xerorthents) \\
\hline
\end{tabular}
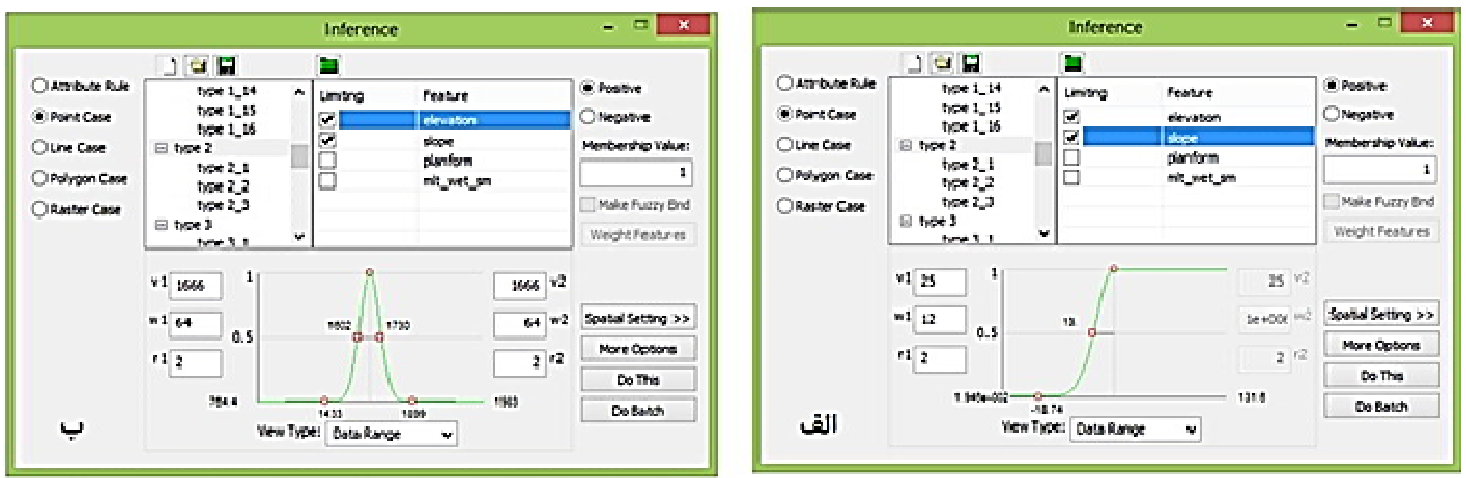

شكل ثا. رابط استنتاج ArcSIE براى خاك نوع دو (Lithic Haploxerepts). الف) منحنى S-shape براى شيب و ب) منحنى Bell-shape براى ارتفاع

O.A $=\frac{\sum_{\mathrm{i}=1}^{\mathrm{c}} \mathrm{E}_{\mathrm{ii}}}{\mathrm{N}}$

در اين رابطه، c تعداد كلاسها، N تعداد كل بيكسل هاى معلوم، دقائ

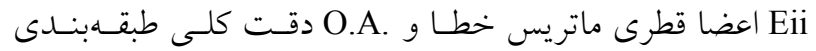
است. بممنظور اعتبارسنجى نقشه توليدى توسط مـــل اسـتنباط

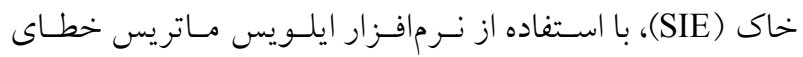
انطباق نقشه رقومى حاصل از مدل و نقشه مرسوم محاسـبه شـد.

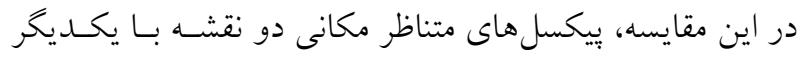

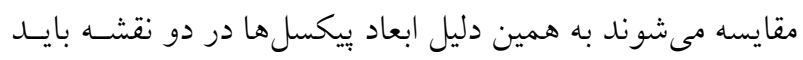
يكسان باشد و هر دو نقش، زمين مرجع باشند.

\section{نتايج و بحث}

جدول (Y) نشانكر نتايج ردهبندى هفت فاميل خاك غالـب موجـود

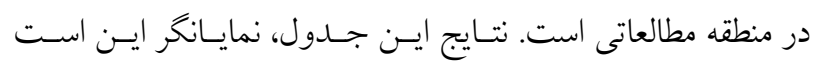

بهنوان خاك آن موقعيت مكانى انتخاب مىشود.

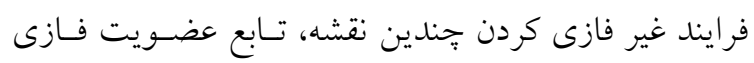

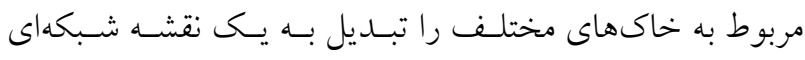

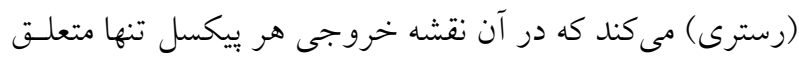

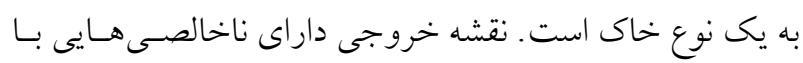

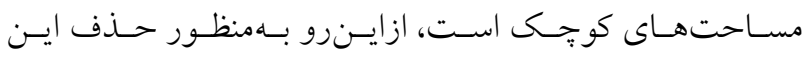
ناخالصى ها از نقشه، ابزار حذف مورد استفاده قرار كرفت.

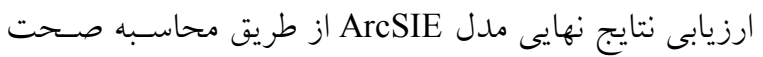

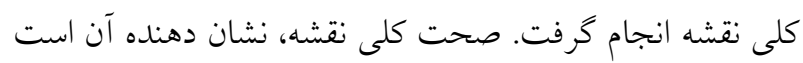
كه تا جهه اندازه مشاهدات يا طبقات جدا شـده، صسحيح هستـند

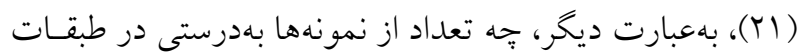

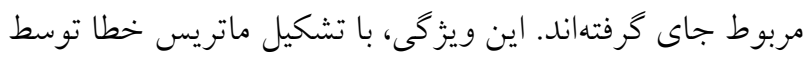

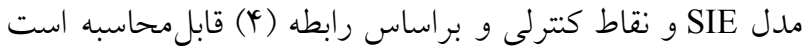




\begin{tabular}{|c|c|c|c|c|}
\hline \multirow{2}{*}{ 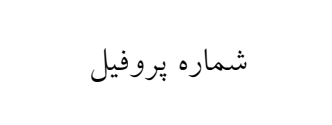 } & \multicolumn{3}{|c|}{ ردهبندى بر اساس طبقهبندى خاى آمريكايى } & \multirow{2}{*}{ فائو } \\
\hline & 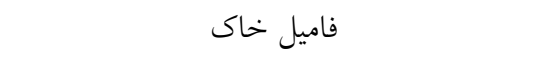 & زيرگروه & رده & \\
\hline r, 11 & Coarse loamy, mixed(calcareous), mesic, & Lithic Xerorthents & Entisols & Eutric Leptosols \\
\hline 0 & Coarse loamy, mixed, mesic, & Lithic Xerorthents & Entisols & Eutric Leptosols \\
\hline 9 & Coarse loamy, mixed, mesic, & Lithic Xerorthents & Entisols & Eutric Leptosols \\
\hline $1, r$ & Fine loamy, mixed(calcareous), mesic, & Lithic Xerorthents & Entisols & Eutric Leptosols \\
\hline $1 V, 11,19$ & Fine loamy, mixed, mesic, & Lithic Haploxerepts & Inceptisols & Leptic Cambisols \\
\hline $9,11,1 \circ, \wedge$ & Coarse loamy, mixed(calcareous), mesic, & Lithic Xerorthents & Entisols & Eutric Leptosols \\
\hline$\uparrow, V, 10,19,14$ & Coarse loamy, mixed(calcareous), mesic & Lithic Xerorthents & Entisols & Eutric Leptosols \\
\hline Ir & Coarse loamy, mixed(calcareous), mesic, & Lithic Xerorthents & Entisols & Eutric Leptosols \\
\hline$r 1, r \circ, r Y, r r, Y Y$ & Fine loamy, mixed(calcareous), mesic, & Typic Calcixerepts & Inceptisols & Haplic Calcisols \\
\hline$r q, r \Lambda, r \vee, r q, r Q$ & Coarse loamy, mixed(calcareous), mesic, & Calcic Haploxerepts & Inceptisols & Calcaric Cambisols \\
\hline 怔 & Coarse loamy, mixed(calcareous), mesic & Typic Xerorthents & Entisols & Eutric Regosols \\
\hline
\end{tabular}

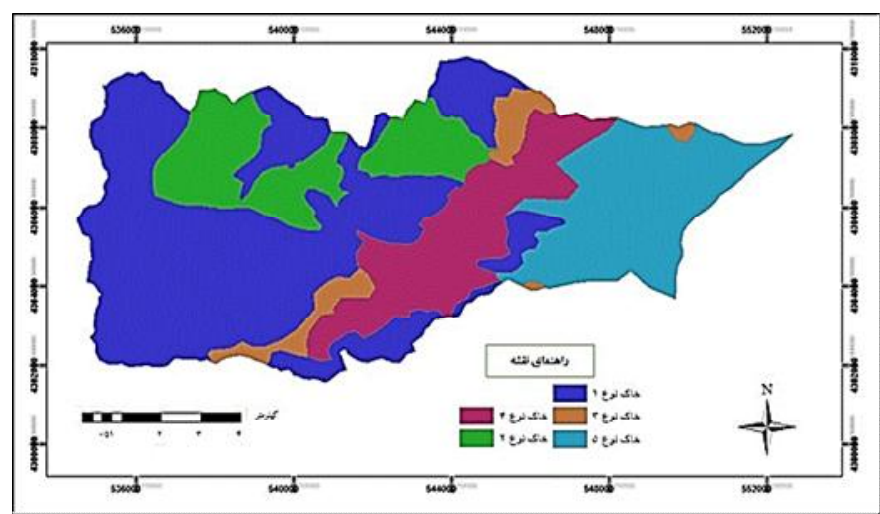

شكل ه. نقشه مرسوم انواع خاكهاى منطقه مورد مطالعه خاى نوع يك (Lithic Xerorthents)، خاى (اك

نوع دو (Cithic Haploxerepts)، خاى نوع سه (Calcic Haploxerepts)، خاى نوع جهار (Typic Calcixerepts) و

خاى نوع ينج (Typic Xerorthents)

نقشه انواع خاى تهيه شد كـه همـان روش مرسـوم تهيـهـ نقشـهـ خاك (شكل ه) است.

نقشههاى خروجى اوليه مدل SIE نتـايج فـازى بـراى هـر

سرى خاك را نشـان مسىدهــ (شـكل 9). در هـر يـك از ايـن

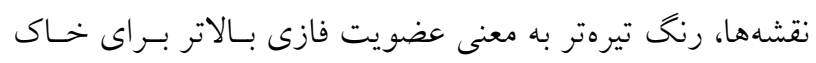

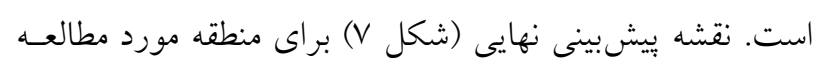

$$
\text { نقشه غير فازى، نتايج SIE است. }
$$

كـه يـنج زيــر خـروه Typic Xerorthents ،Lithic Xerorthents Calcic Haploxerepts و Lithic Haploxerepts ، Typic Calcixerepts

$$
\begin{aligned}
& \text { زيرگروههاى غالب منطقه هستند. } \\
& \text { براساس مطالعـات انجـام كرفتـه ستادى و صـحرايى كـهـ } \\
& \text { براساس تفسير عكسهاى هوايى، نقشه تويو گرافى منطقه، نقشه } \\
& \text { زمينشناسى و نيز انطباق آنها با بيمايش صحرايى انجام كرفـت، }
\end{aligned}
$$

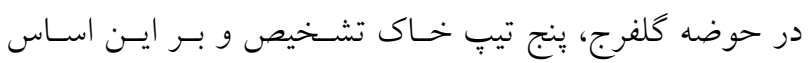




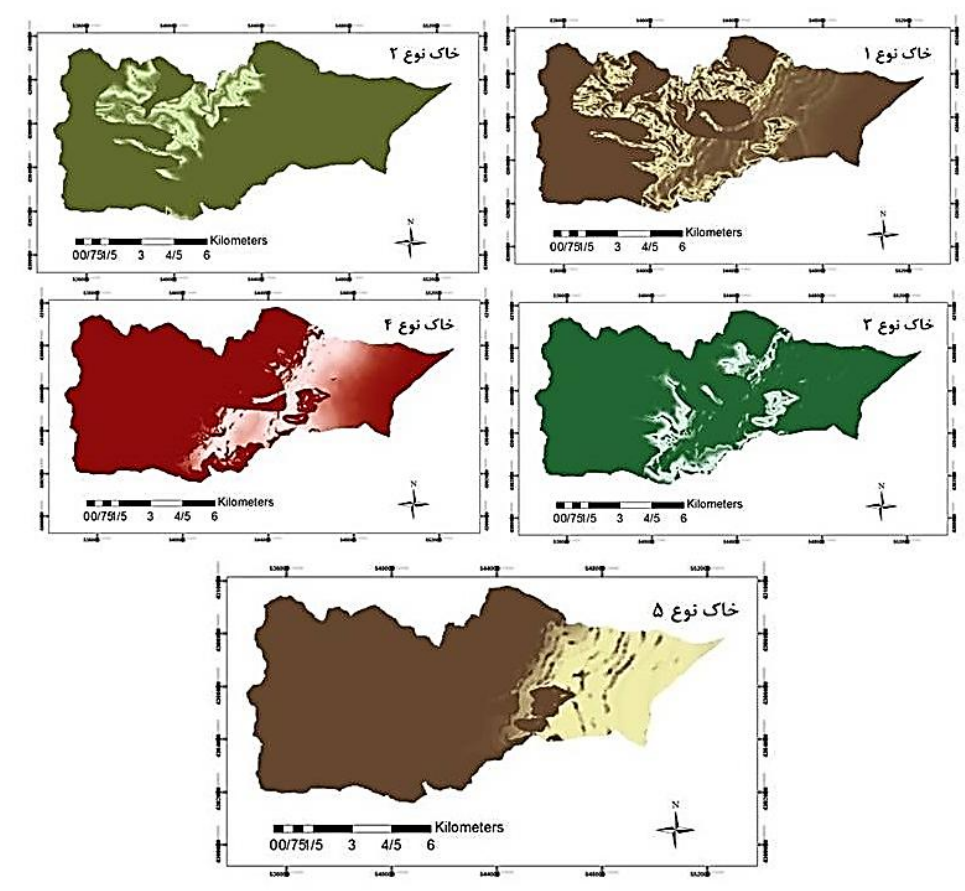

شكل צ. نقشه بيشبينى فازى براى خاك نوع يك (Lithic Xerorthents)، خاك نوع دو (Lithic Haploxerepts)، خاك نوع سه (Calcic Haploxerepts)، خاك نوع جهار (Typic Calcixerepts) و خاى نوع پينج (Typic Xerorthents) در منطقه مورد مطالعه

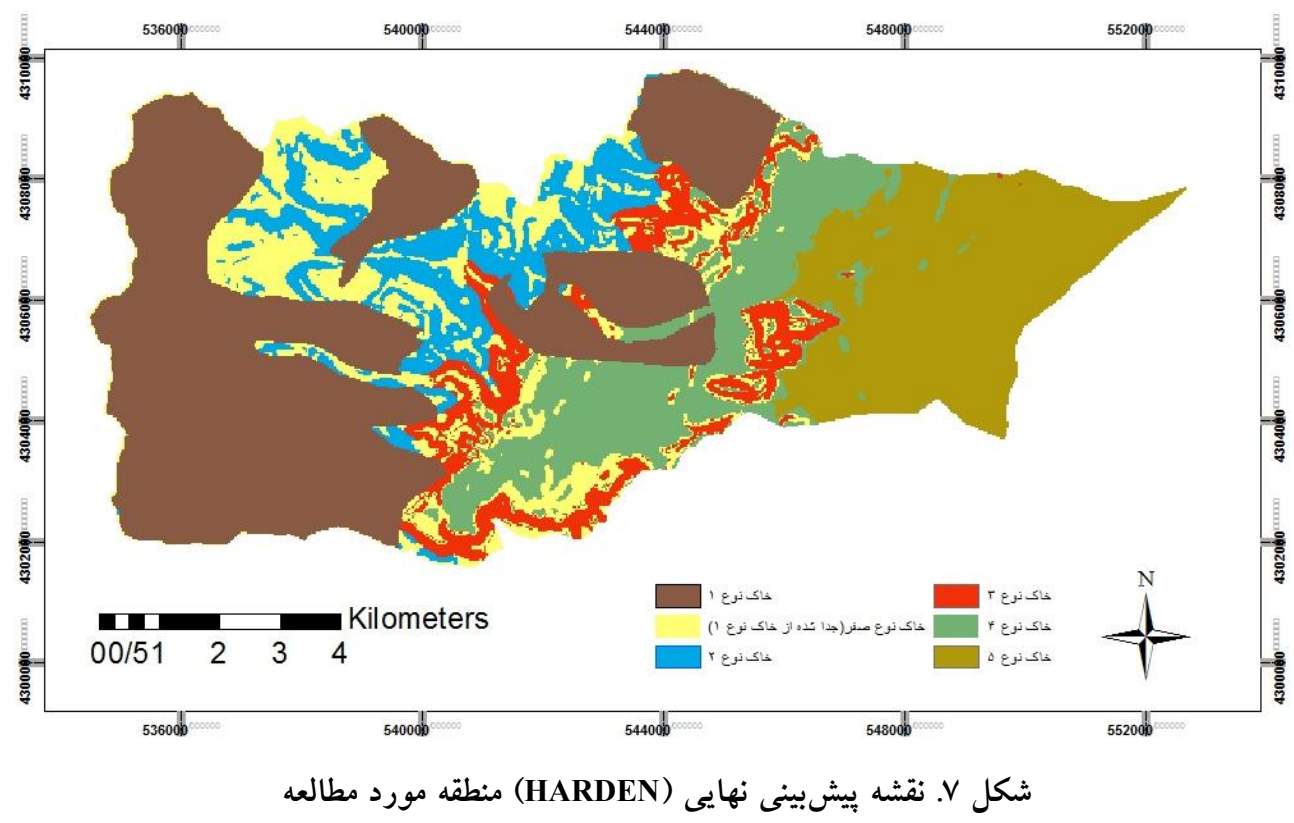

\footnotetext{
آمده بـهـــور قابـل تـوجهى قـدرت تفكيـى مكـانى، توزيـع و نقشه رقومى سرىهاى خاك كه بهوسيله غير فـازى كـردن

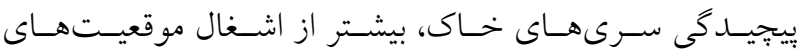
ايجاد شدهاند، كلاسهاى با بالاترين مقادير عضويت فازى براى تويوگر افى در زمين نما است. خاك نوع يك در نقشه يـيشبينسى

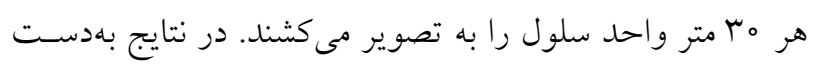


جداسازى واحدهاى خاك است. اعتبارسـنجى نقشـه استخراج

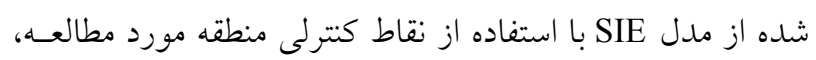

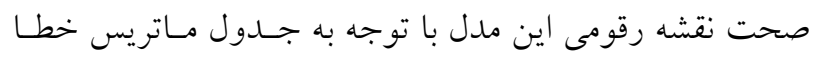

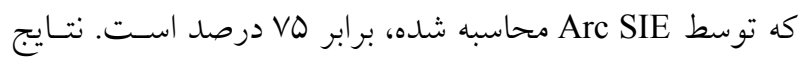

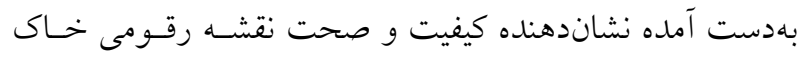

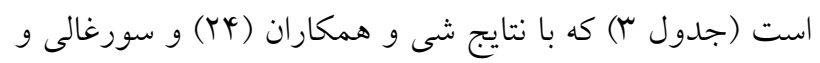

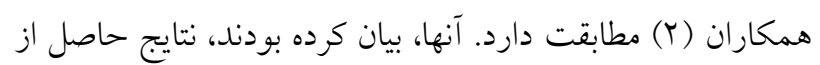

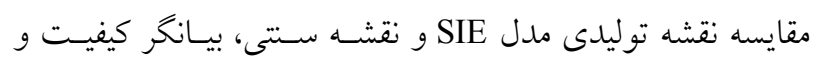

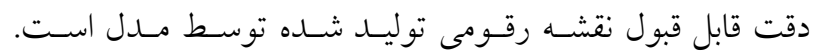

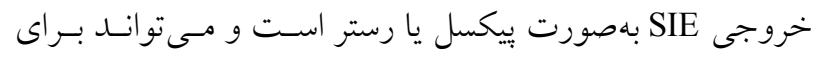

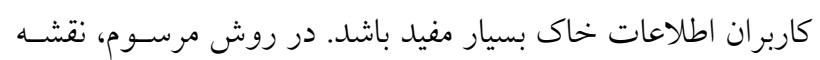

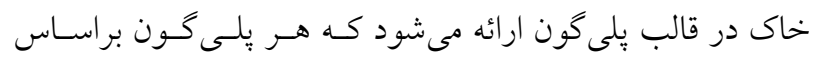

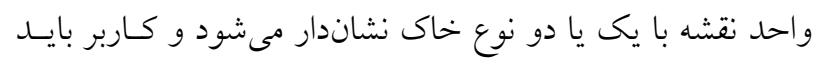

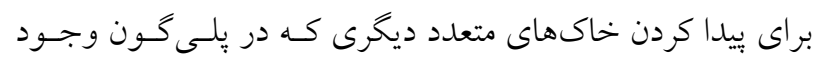

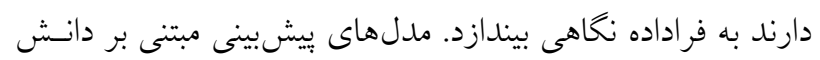

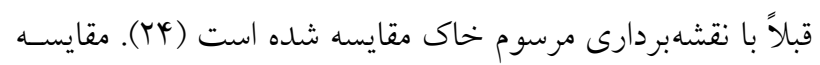

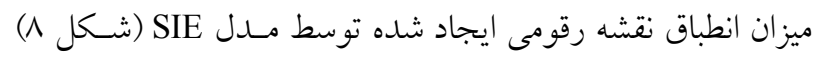

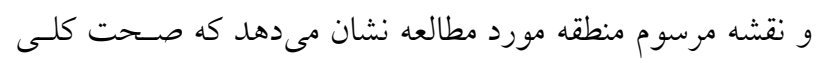

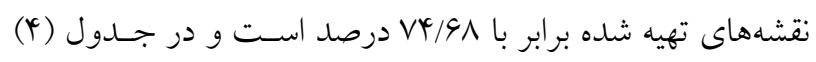
آورده شده است. در مطالعه ديخرى سـورغالى در حوضـهـ آبخيـز

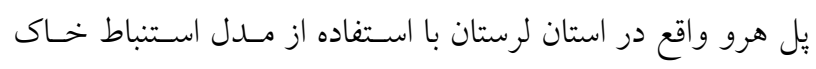
SIE

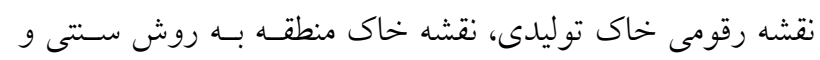

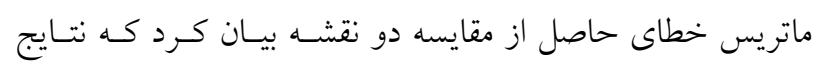

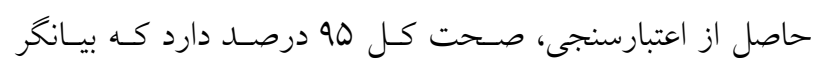

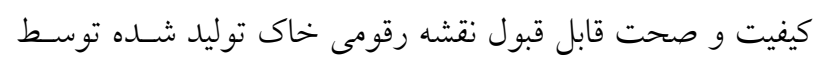

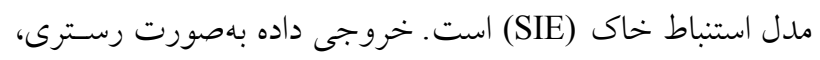

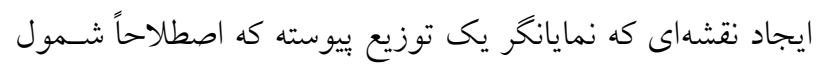

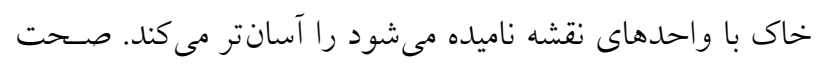

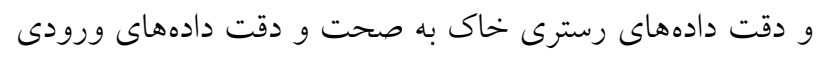

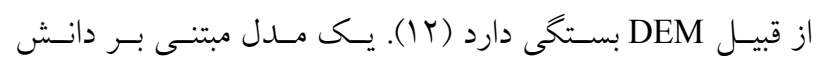
مانند، SIE، يتانسيل بيشبينى خواص مستمر خاك را دارد.
نهايى (HARDEN) توسط مدل SIE بـه دو قسمت بانـامهـاى

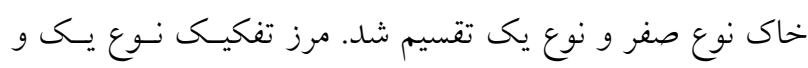

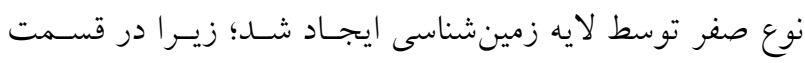

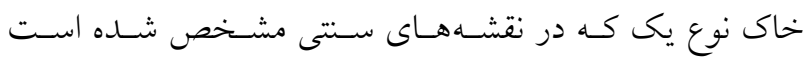

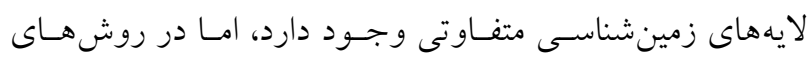

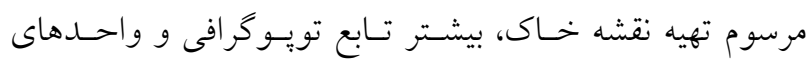

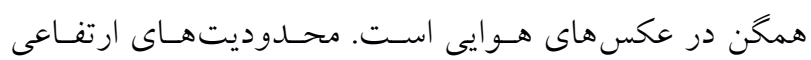

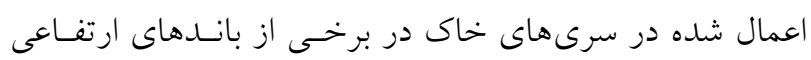

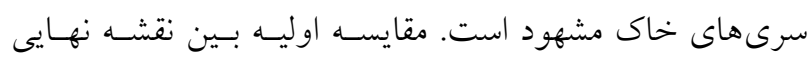

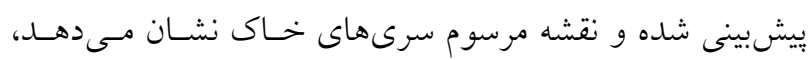

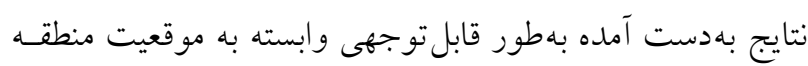

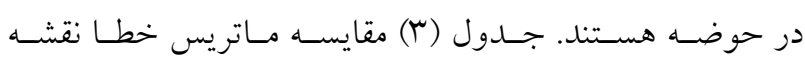

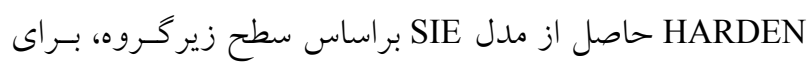

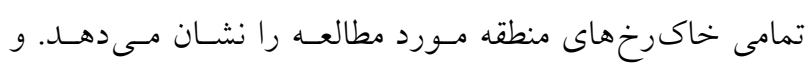

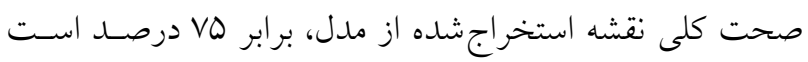

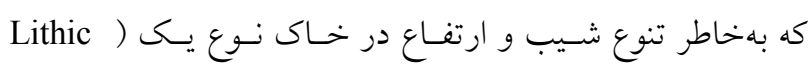
Xerorthents

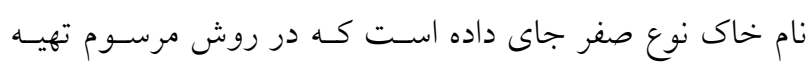

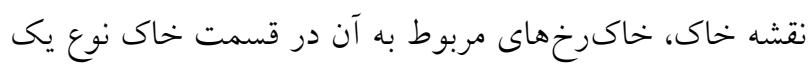

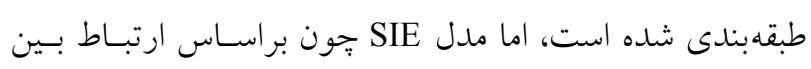

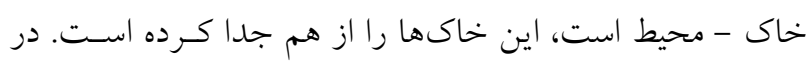

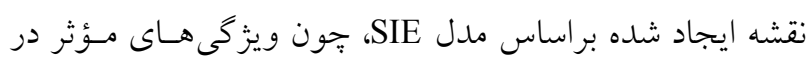

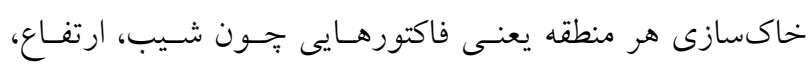

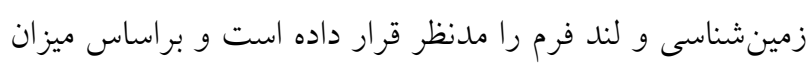

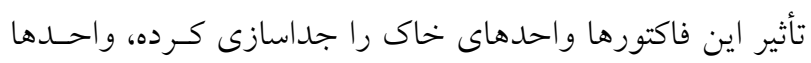

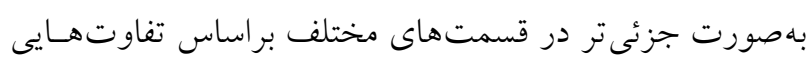
كه شيب و ارتفاع و حتى زمينشناسى آن قسمت ها باهم دارنــد،

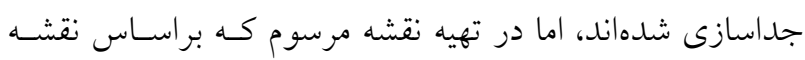

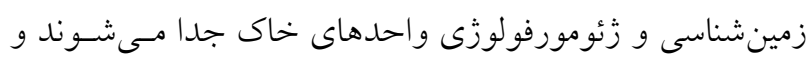

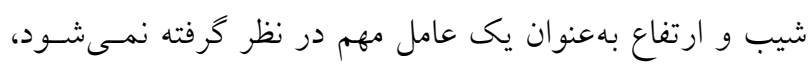

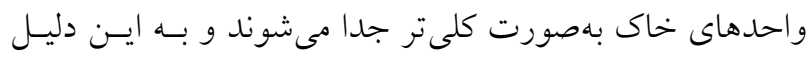
است كه نقشه ايجاد شده از مدل SIE، داراى دقـت بـالاترى در 


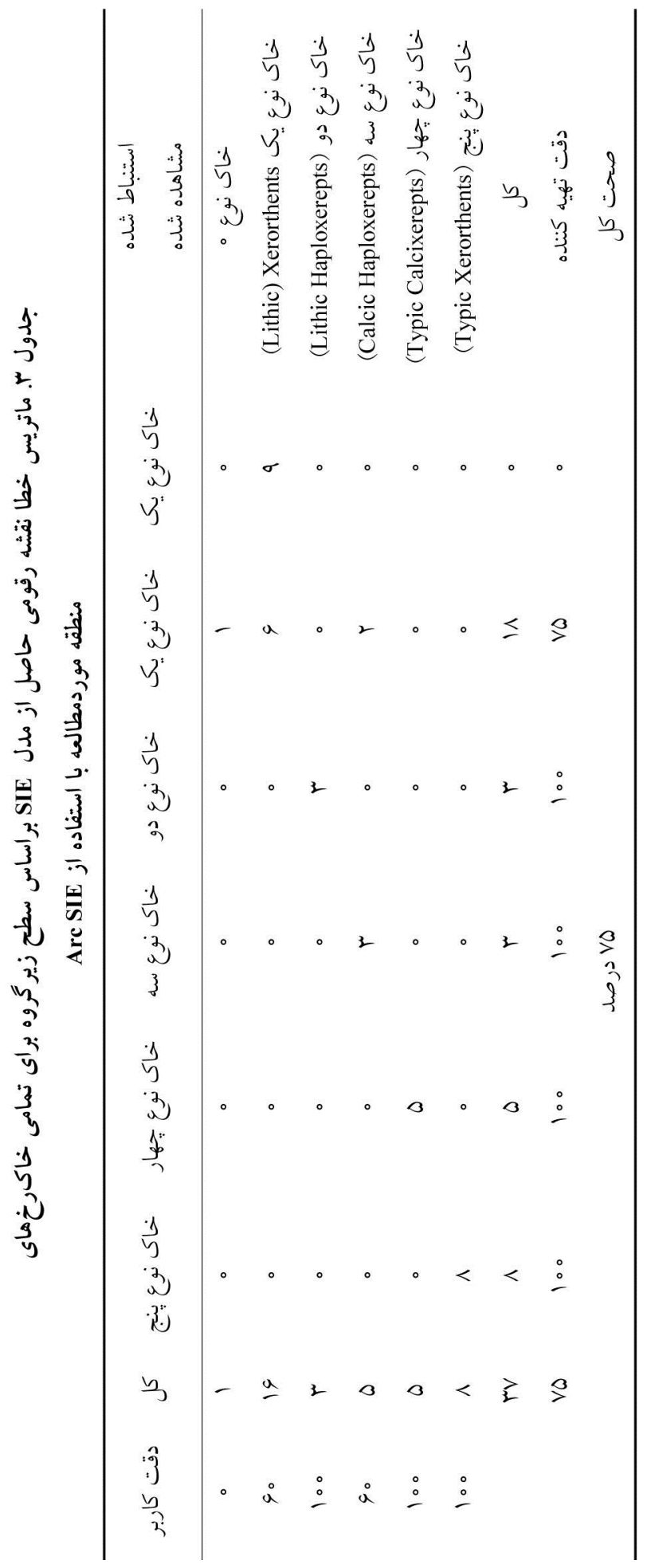




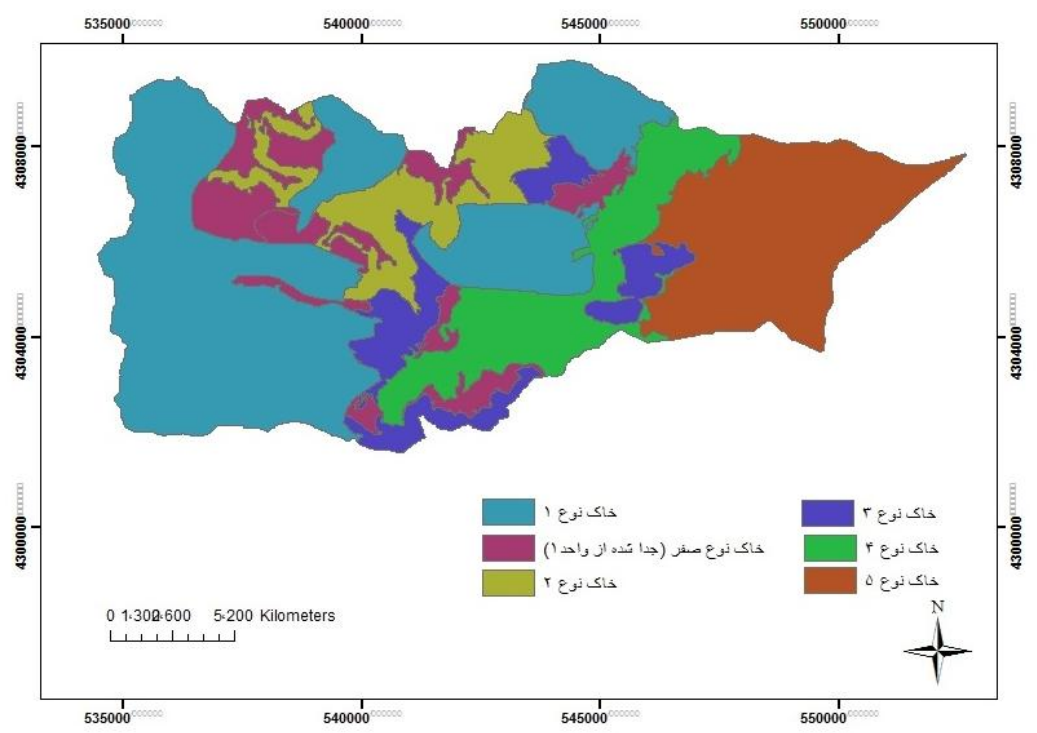

شكل ^. نقشه نهايى وكتور شده منطقه مطالعاتى با استفاده از مدل SIE براى خاك نوع يك (Lithic Xerorthents)، خاى نوع دو (Cithic Haploxerepts)، خاى نوع سه (Calcic Haploxerepts)، خاى نوع جهار (Typic Calcixerepts) و خاك نوع ينج (Typic Xerorthents)

جدول fا. ماتريس خطاى انطباق نقشه هاى حاصل از روش مرسوم و مدل SIE (برحسب بيكسل) با استفاده از نرمافزار ILWIS

\begin{tabular}{|c|c|c|c|c|c|c|c|c|}
\hline صحت & كل & طبقهبندى نشده & خاى نوع & خاك نوع & خاك نوع & خاك نوع & خاك نوع & مشاهده شدنباط شده \\
\hline$\circ / N Q$ & IIVqry & 。 & 。 & vor。 & gorv & 14900 & M M91r & خاك نوع يك (Lithic Xerorthents) \\
\hline$\circ / N r$ & $r \circ \Delta \circ r^{2}$ & 。 & 。 & 。 & 。 & 14994 & $\Delta Q \Delta V$ & خاى نوع دو (Lithic Haploxerepts) \\
\hline$\circ / \circ 9$ & $1 \wedge 1 \wedge 0$ & $\circ$ & $\Lambda q Y$ & rav & IVQY & MVt & ITOKA & خاى نوع سه (Calcic Haploxerepts) \\
\hline$\circ / 19$ & rNIYq & $\circ$ & 1001 & $r \Delta \circ \Delta \Delta$ & $10 \wedge 9$ & 。 & $90 \mathrm{~V}$ & خاك نوع جهار (Typic Calcixerepts) \\
\hline$\circ / 94$ & FIFV & $\circ$ & MAMY & $190 \circ$ & 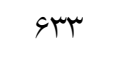 & $\circ$ & $9 \Lambda$ & خاك نوع ينج (Typic Xerorthents) \\
\hline & rTGQYA & 。 & $y \circ V+1$ & ryq०r & 10010 & 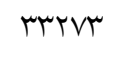 & I०N०Kr & كل \\
\hline & & & $\circ / 90$ & $\circ / V Y$ & $\circ / 1$ & $\circ / 4 \Delta$ & $\circ / \Lambda T$ & قابليت اطمينان \\
\hline \multicolumn{8}{|c|}{ | } & صحت كل \\
\hline
\end{tabular}

بيشتر بهمنظور بررسى مسئله يـيشبينى خــواص مسـتمر خـاك مورد نياز است. در اين مطالعه نيز محدوديت هاى منطقـه مـورد مطالعه با دانش كارشناسى تعيين شــده، آستانههـاى مـورد نيـاز توابع مشخص شده و نقشه رقومى خاك با درصد صحت قابسل قبولى بهدست آمده است. مهمترين قسمت در مـدل SIE همـان شناسايى محدوديتها و آستانهها است. استفاده از ArcSIE، مديريت مؤثر دادهها و ارائه يـك رويسه
تتيجه كيرى ويزگ گىهاى خاك در منطقه مورد مطالعه با استفاده از مدل مبتنى هـ بر دانش منطق فازى مدلسازى شده اسـت. مــل ويزخىىهـى خاى مى تواند مفهومى شود و لايههاى دادههاى زيستمحيطى در دسترس، اجازه انتقال اين دانش به مدل و اسـتنتاج را فـراهم

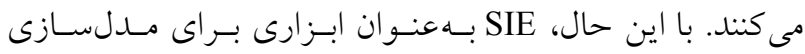
ويز كى هاى خاى آزمايش نشده است، بنابراين تحقيق و توسـعه 


$$
\begin{aligned}
& \text { ارتفاع هم به لحاظ منطقى و رياضى و هم از نظر تجربسى، داراى }
\end{aligned}
$$

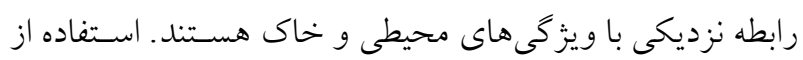

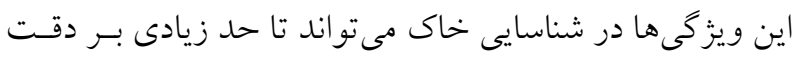

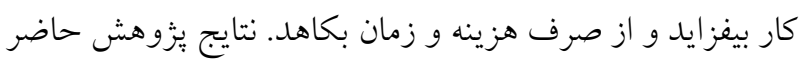

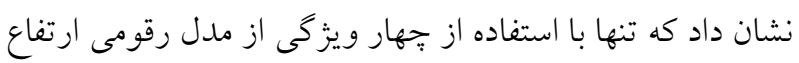

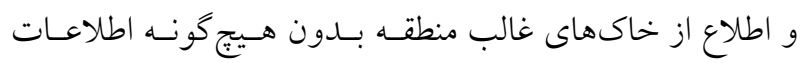

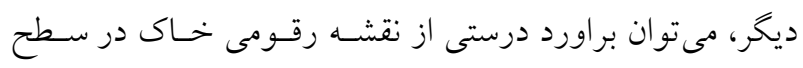

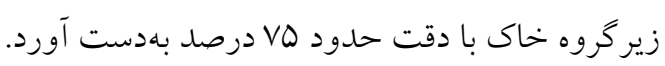

$$
\begin{aligned}
& \text { منابع مورد استفاده }
\end{aligned}
$$

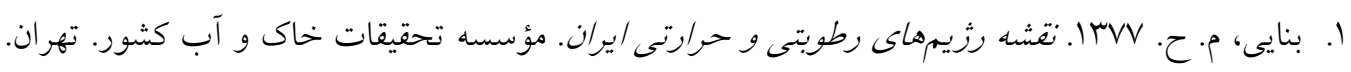

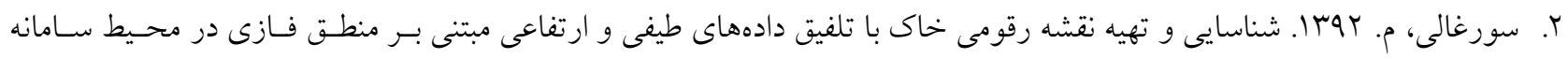

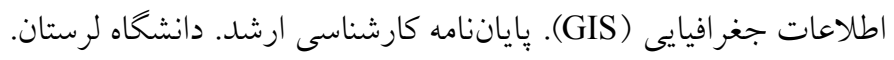

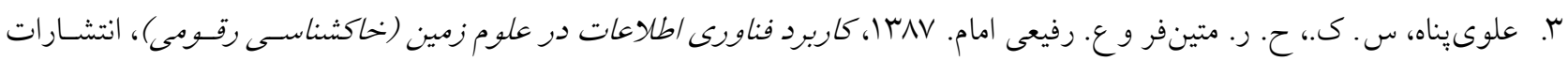

$$
\begin{aligned}
& \text { دانشخاه تهر ان. تهران }
\end{aligned}
$$

4. Cook, S. E., R. J. Corner, G. Grealish, P. E. Gessler and C. J. Chartress. 1996. A rule-based system to map soil properties. Soil Science Society of America Journal 60:1893-1900.

5. Esfandiarpoor Borujeni, I., J. Mohammadi, M. H. Salehi, N. Toomanian and R. M. Poch. 2010. Assessing geopedological soil mapping approach by statistical and geostatistical methods: A case study in the Borujen region, Central Iran. Catena 82: 1-14.

6. Grunwald, S. 2006. Environmental Soil-Landscape Modeling, Geomorphic Information Technologies and Pedometrics. Taylor and Francis, New York.

7. Grunwald, S. 2006. What do we really know about the space-time continuum of soil- landscapes. PP: 3-36. In: Environmental Soil Landscape Modeling, Geographic Information Technologies and Pedometrics. Taylor and Francis, New York.

8. Jafari, A., S. Ayoubi, H. Khademi, P. A. Finke and N. Toomanian. 2013. Selection of a taxonomic level for soil mapping using diversity and map purity indices: a case study from an Iranian arid region. Geomorphology 201: 86-97.

9. Jafari. A., P. A. Finke, J. Van deWauw, S. Ayoubi and H. Khademi. 2012. Spatial prediction of USDA- great soil groups in the arid Zarand region, Iran: comparing logistic regression approaches to predict diagnostic horizons and soil types. European Journal of Soil Science 63: 284-298.

10. Kempen, B., D. J. Brus and G. B. M. Heuvelink. 2012. Soil type mapping using the generalized linear geostatistical model: a case study in a Dutch cultivated peatland. Geoderma 189: 540-553.

11. Kempen, B., D. J. Brus, G. B. M. Heuvelink and J. J. Stoorvogel. 2009. Updating the 1:50 000 Dutch soil map using legacy soil data: A multinomial logistic regression approach. Geoderma 151: 311-326.

12. Legros, J. P. 2006. Mapping of the Soil. Science Publishers, NH, USA.

13. Luo, Y. M., Z. G. Li, L. H. Wu, S. C. Wu, G. L. Zhang, S. L. Zhou, Y. G. Zhao, Q. G. Zhao, M. H. Wong. and H. B. Zhang. 2007. Hong Kong Soils and Environment (in Chinese). Science Press, Beijing.

14. McBratney, A. B. 2006. Background to digital soil mapping. In: Proceeding of the International Working Group on Digital Soil Mapping. Retrieved April 23, 2007 from http://www.digitalsoilmapping.org/DSM_Background.html. Pedometrics. Taylor and Francis.

15. McBratney, A. B., M. L. Mendonca-Santos and B. Minasny. 2003. on digital soil mapping. Geoderma 117:30-52.

16. McKay, J, S. Grunwald, X. Shi and R. F. Long. 2010. Evaluation of the transferability of a knowledge-based soil- 
Landscape model. Digital Soil Mapping Progress in Soil Science 2: 165-178

17. McKay, J. 2008. Using a knowledge-based system to test the transferability of a soil-landscape model in northeastern vermont. MSc. Thesis, University of Florida, Gainesville, FL.

18. Pahlavan Rad, M. R., N. Toomanian, F. Khormali, C. W. Brungard, C. B. Komaki and P. Bogaert. 2014. Updating soil survey maps using random forest and conditioned Latin hypercube sampling in the loess derived soils of northern Iran. Geoderma 232-234: 97-106.

19. Pennock, D. J, B. J. Zebarth and E. Dejong. 1987. Landform classification and soil distribution in Hummocky terrain, Saskatchewan, Canada. Geoderma 40: 297-315.

20. Rhoades, J. D. 1982. Soluble salts. PP. 933-951. In: A. L. Page (Ed.), Methods of Soil Analysis, Part II $2^{\text {nd }}$, Agronomy Monograph.ASA, Madison, WI.

21. Rossiter, D. G. 2000. Methodology for Soil Resource Inventories, 2nd Revised Version, Soil Science Division, International Institute for Aerospace Survey \& Earth Science (ITC). Enschede the Netherlands.

22. Schoeneberger, P. J., D. A. Wysocki, E. C. Benham and W. D. Broderson. 2002. Field Book for Describing and Sampling soils, Version 2.0. (No. 631.47). National Soil Survey Center, Natural Resources Conservation Service.

23. Scull, P. R. 2002. Predictive soil mapping in the Mojave Desert of California. PhD. Thesis. University of California, San Diego State University.

24. Shi, X., A. X. Zhu, J. E. Burt, F. Qi, and D.Simonson. 2004. A case-based reasoning approach to fuzzy soil mapping. Soil Science Society of America Journal 68: 885-894.

25. Smith, S., C. Bulmer, E. Flager, G. Frank and D. Filatow. 2010. Digital soil mapping at multiple scales in British Columbia, Canada. In: Proceeding of the $4^{\text {th }}$ Global Workshop on Digital Soil Mapping, Rome, Italy.

26. Soil Survey Staff. 2010. Keys to Soil Taxonomy (1 $1^{\text {th }}$ Ed). NRCS, USDA, USA

27. Taghizadeh-Mehrjardi, R., B. Minasny, A. B. McBratney, J. Triantafilis, F. Sarmadian and N. Toomanian. 2012. Digital soil mapping of soil classes using decision trees in central Iran. Digital Soil Assessments and Beyond. In: Proceedings of the $5^{\text {th }}$ Global Workshop on Digital Soil Mapping, Sydney, Australia.

28. Zhu, A., B. Hudson, J. Burt, K. Lubich. and D. Simonson. 2001. Soil mapping using GIS, expert knowledge, and fuzzy logic. Soil Science Society of America Journal 65: 1463-1472. 


\title{
Evaluation of Soil Inference Model (SIE) in Soil Mapping with Emphasis on Using Expert Knowledge and Fuzzy Logic (Jolfa City-Golfaraj)
}

\author{
A. Fariabi* and H. Matinfar ${ }^{1}$
}

(Received: April 7-2015 ; Accepted: October 24-2017)

\begin{abstract}
One of the problems with the traditional mapping of soils is the expert's opinion, it time-consuming and timely preparation, and the updating of the maps. While digital soil mapping, using different soil-earth models leads to the simplification of the complexity of the soil system. The purpose of this study was to investigate Soil-Environment Inference (SIE) in soil mapping with an emphasis on using the expert knowledge and fuzzy logic. For this purpose, the digital layer of geology and peripheral layers were derived from a digital elevation model including elevation, slope, and curvature of the ground surface, and auxiliary index, which comprised the input data of the SIE model. Then, the fuzzy maps prepared for the five soil types and the final map of soil prediction were created by hardening. The results showed that the SIE model, which used environmental variables, had a high ability to isolate soil types with more detailed compositions of soils with different maternal materials. The comparison of the error matrix showed that the overall accuracy of the derived map of the SIE model was equal to $75 \%$, and the matching of the digital mapping results with conventional mapping accounted for $74.71 \%$ of the results. The difference in the compliance rate could be attributed to the difference in the nature of the two methods.
\end{abstract}

Keywords: Digital soil mapping, Digital elevation model, Fuzzy logic, SIE model

1. Department of Soil Science, Faculty of Agriculture, Lorestan Uninersity, Lorestan, Iran.

*: Corresponding Author, Email: azarfariabi@gmail.com 